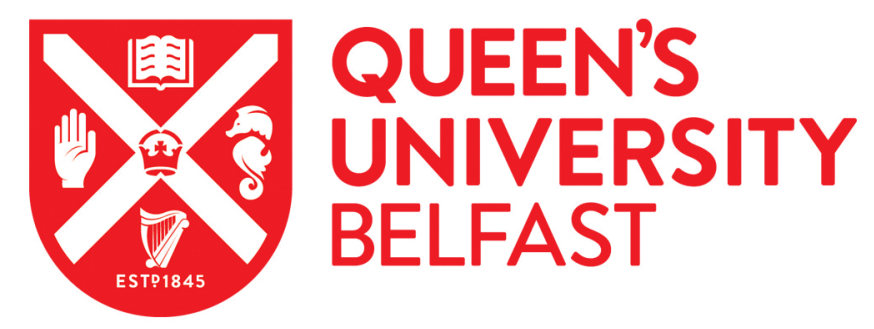

\title{
Influence of external zinc and phosphorus supply on Cd uptake by rice (Oryza sativa L.) seedlings with root surface iron plaque
}

Liu, H. J., Zhang, J. L., Christie, P., \& Zhang, F. S. (2007). Influence of external zinc and phosphorus supply on Cd uptake by rice (Oryza sativa L.) seedlings with root surface iron plaque. Plant and Soil, 300(1-2), 105-115. https://doi.org/10.1007/s11104-007-9393-3

Published in:

Plant and Soil

Queen's University Belfast - Research Portal:

Link to publication record in Queen's University Belfast Research Portal

\section{General rights}

Copyright for the publications made accessible via the Queen's University Belfast Research Portal is retained by the author(s) and / or other copyright owners and it is a condition of accessing these publications that users recognise and abide by the legal requirements associated with these rights.

Take down policy

The Research Portal is Queen's institutional repository that provides access to Queen's research output. Every effort has been made to ensure that content in the Research Portal does not infringe any person's rights, or applicable UK laws. If you discover content in the Research Portal that you believe breaches copyright or violates any law, please contact openaccess@qub.ac.uk. 


\title{
Influence of external zinc and phosphorus supply on $\mathbf{C d}$ uptake by rice (Oryza sativa L.) seedlings with root surface iron plaque
}

\author{
H. J. Liu • J. L. Zhang • P. Christie • F. S. Zhang
}

Received: 20 March 2007 / Accepted: 10 August 2007 / Published online: 20 September 2007

(C) Springer Science + Business Media B.V. 2007

\begin{abstract}
Rice seedlings were grown in hydroponic culture to determine the effects of external $\mathrm{Zn}$ and $\mathrm{P}$ supply on plant uptake of $\mathrm{Cd}$ in the presence or absence of iron plaque on the root surfaces. Iron plaque was induced by supplying $50 \mathrm{mg} \mathrm{l}^{-1} \mathrm{Fe}^{2+}$ in the nutrient solution for 2 day. Then 43-day-old seedlings were exposed to $10 \mu \mathrm{mol} \mathrm{l}^{-1} \mathrm{Cd}$ together with $10 \mathrm{mmol} \mathrm{l}^{-1} \mathrm{Zn}$ or without $\mathrm{Zn}$ ( $\mathrm{Zn}-\mathrm{Cd}$ experiment), or to $10 \mu \mathrm{mol} \mathrm{l}^{-1}$ $\mathrm{Cd}$ with $1.0 \mathrm{mmol}^{-1} \mathrm{P}$ or without $\mathrm{P}(\mathrm{P}-\mathrm{Cd}$ experiment) for another 2 day. The seedlings were then harvested and the concentrations of Fe, Zn, P and $\mathrm{Cd}$ in dithionite-citrate-bicarbonate (DCB) extracts and in roots and shoots were determined. The dry weights of roots and shoots of seedlings treated with
\end{abstract}

Responsible Editor: Fangjie J. Zhao.

H. J. Liu · J. L. Zhang $\cdot$ P. Christie $\cdot$ F. S. Zhang

Key Laboratory of Plant Nutrition, Ministry of Agriculture,

China Agricultural University,

Beijing 100094, China

H. J. Liu · J. L. Zhang $\cdot$ P. Christie $\cdot$ F. S. Zhang

Key Laboratory of Plant-Soil Interactions,

Ministry of Education, China Agricultural University,

Beijing 100094, China

H. J. Liu · J. L. Zhang $(\bowtie) \cdot$ P. Christie $\cdot$ F. S. Zhang

College of Resources and Environmental Sciences,

China Agricultural University,

Beijing 100094, China

e-mail: junlingz@cau.edu.cn
$50 \mathrm{mg} \mathrm{l}^{-1}$ Fe were significantly lower than when no Fe was supplied. Adsorption of $\mathrm{Cd}, \mathrm{Zn}$ and $\mathrm{P}$ on the iron plaque increased when $\mathrm{Fe}$ was supplied but $\mathrm{Cd}$ concentrations in DCB extracts were unaffected by external $\mathrm{Zn}$ or $\mathrm{P}$ supply levels. Cd concentrations in shoots and roots were lower when Fe was supplied. Zn additions decreased $\mathrm{Cd}$ concentrations in roots but increased $\mathrm{Cd}$ concentrations in shoots, whereas $\mathrm{P}$ additions significantly increased shoot and root $\mathrm{Cd}$ concentrations and this effect diminished when Fe was supplied. The percentage of $\mathrm{Cd}$ in DCB extracts was significantly lower than in roots or shoots, accounting for up to $1.8-3.8 \%$ of the plant total $\mathrm{Cd}$, while root and shoot $\mathrm{Cd}$ were within the ranges $57-76 \%$ and $21-40 \%$ respectively in the two experiments. Thus, the main barrier to Cd uptake seemed to be the root tissue and the contribution of iron plaque on root surfaces to plant

H. J. Liu

College of Soil and Environmental Sciences,

Shenyang Agricultural University,

Shenyang 110161, China

P. Christie

Agricultural and Environmental Science Department,

Queen's University Belfast,

Belfast BT9 5PX, UK 
$\mathrm{Cd}$ uptake was minor. The changes in plant $\mathrm{Cd}$ uptake were not due to $\mathrm{Zn}$ or $\mathrm{P}$ additions altering $\mathrm{Cd}$ adsorption on iron plaque, but more likely because $\mathrm{Zn}$ or $\mathrm{P}$ interfered with $\mathrm{Cd}$ uptake by the roots and translocation to the shoots.

Keywords Cadmium - Iron plaque - Oryza sativa . Phosphorus $\cdot$ Zinc

\section{Introduction}

Cadmium is of great concern due to its threat to the food chain and human health. General interest in $\mathrm{Cd}$ in rice arose with the occurrence of Itai-Itai disease in Japan caused by $\mathrm{Cd}$ intake from rice (Obata and Umebayashi 1997). Tsukahara et al. (2003) showed that rice was the most important source of $\mathrm{Cd}$ in the Japanese diet, accounting for $30-40 \%$ of total $\mathrm{Cd}$ intake (Watanabe et al. 2000). Cd pollution of paddy soils originates mainly from industrial processes and phosphatic fertilizers or manures, together with irrigation with contaminated wastewater (Junta et al. 1998). Once discharged, Cd is highly persistent in the environment. It is readily absorbed by and translocated within rice plants (Shah et al. 2001), and Cd accumulation in rice grain can pose a high potential risk to human health despite the occurrence of lower $\mathrm{Cd}$ concentrations in polished than in unpolished rice grain (Kim et al. 1980). A recent literature survey (J. L. Zhang, unpublished) has indicated that the transfer coefficient of $\mathrm{Cd}$ between rice shoots and grain ranges from about 11 to $40 \%$ and depends on the soil type, plant genotype and environmental conditions. Lowering shoot $\mathrm{Cd}$ uptake is therefore of prime importance for reducing $\mathrm{Cd}$ concentrations in rice grain.

There are many factors affecting Cd uptake by rice (Chaney and Hornick 1978). The ubiquity of iron plaque observed on rice root surfaces has stimulated investigations on the effects of iron plaque on plant elemental uptake. The formation of iron plaque on the root surfaces of rice and other wetland plants is due to the release of oxygen and oxidants in the rhizosphere and the subsequent oxidation of ferrous to ferric iron and the precipitation of iron oxide or hydroxide on the root surface (Armstrong 1967; Chen et al. 1980b;
Taylor et al. 1984). Mineralogical investigations in wetland fields have shown that the composition of iron plaque in Phalaris arundinacea is mainly ferrihydrite $(\sim 63 \%)$ with smaller amounts of goethite $(32 \%)$ and minor amounts of siderite (5\%) Hansel et al. 2001), or predominately goethite in Juncus bulbosus (Chabbi 1999) and rice (Chen et al. 1980a). Iron plaque therefore has chemical properties similar to those of iron oxides in the soil and can thus sequester both cations and anions and alter the uptake and accumulation of elements by plants. Iron plaque on rice root surfaces has been shown to sequester As (Liu et al. 2004a,b and Liu et al. 2005), Al (Chen et al. 2006) and Se (Zhou et al. 2007), alleviate toxicities of $\mathrm{Cu}, \mathrm{Ni}$ and $\mathrm{Zn}$ to plants (Greipsson 1994, 1995; Greipsson and Crowder 1992) and enhance Zn uptake when the amount of iron plaque was up to $12.1 \mathrm{~g} \mathrm{~kg}^{-1}$ root dry weight (Zhang et al. 1998) and $\mathrm{P}$ uptake up to $24.5 \mathrm{~g} \mathrm{~kg}^{-1}$ root dry weight when $\mathrm{Fe}(\mathrm{OH})_{3}$ was supplied to induce the formation of iron plaque (Zhang et al. 1999). However, studies have also suggested that iron plaque is not the main barrier to Cd uptake by rice (Liu et al. 2007).

$\mathrm{Zn}$ and $\mathrm{P}$ are commonly associated with $\mathrm{Cd}$ in natural or anthropogenic sources. The chemical similarity of $\mathrm{Cd}$ and $\mathrm{Zn}$ leads to the co-existence of the two elements, and both antagonistic and synergistic interactions in plant uptake have been reported in hydroponic and field experiments (Hart et al. 2005; Kukier and Chaney 2002). $P$ fertilizers are regarded as an important source of Cd pollution in cultivated soils, and $\mathrm{Cd}$ and $\mathrm{P}$ may have synergistic interactions (Lagriffoul et al. 1998; Moral et al. 1994).

Most published studies on rice have focused on the role of iron plaque in the uptake of one single element. However, a study by Geng et al. (2005) showed that As uptake by rice may involve a three-way interaction among $\mathrm{P}$ supply, the amount of iron plaque and uptake of As but the underlying mechanisms remain unclear. Taking together the significant role of $\mathrm{Zn}$ and $\mathrm{P}$ supply in rice $\mathrm{Cd}$ uptake and the contribution of iron plaque to elemental uptake by plants, the present study was conducted to investigate the effects of external $\mathrm{Zn}(\mathrm{Zn}-$ $\mathrm{Cd}$ experiment) or $\mathrm{P}$ supply levels ( $\mathrm{P}-\mathrm{Cd}$ experiment) on $\mathrm{Cd}$ uptake by rice seedlings with root surface iron plaque. Our hypothesis was that the presence of $\mathrm{Zn}$ or 
$\mathrm{P}$ may lower the adsorption of $\mathrm{Cd}$ on root surface iron plaque and thus depress the uptake and accumulation of Cd by rice seedlings.

\section{Materials and methods}

Pre-culture of rice seedlings

Seeds of rice (Oryza stativa L. cv. II You 718) were surface sterilized in $30 \% v / v \mathrm{H}_{2} \mathrm{O}_{2}$ for $30 \mathrm{~min}$ and then washed thoroughly with deionized water. Afterwards the seeds were dipped in saturated $\mathrm{CaSO}_{4}$ solution for $6 \mathrm{~h}$ to promote germination and then germinated in acid-washed quartz sand for 10 day. Each seedling was transferred to a 1.2-1 ceramic container and grown in 1/2-strength nutrient solution for 3 day and then for a further 26 days in full strength solution with the following nutrient composition $\left(\mu \mathrm{mol} \mathrm{l} \mathrm{l}^{-1}\right)$ : $\mathrm{NH}_{4} \mathrm{NO}_{3}$ 500, $\mathrm{NaH}_{2} \mathrm{PO}_{4} \cdot 2 \mathrm{H}_{2} \mathrm{O} 60, \mathrm{~K}_{2} \mathrm{SO}_{4} 230, \mathrm{CaCl}_{2} 210$, $\mathrm{MgSO}_{4} \cdot 7 \mathrm{H}_{2} \mathrm{O} 160$, Fe-EDTA $10, \mathrm{ZnSO}_{4} \cdot 7 \mathrm{H}_{2} \mathrm{O} 0.5$, $\mathrm{MnCl}_{2} \cdot 4 \mathrm{H}_{2} \mathrm{O} 0.5,\left(\mathrm{NH}_{4}\right)_{6} \mathrm{Mo}_{7} \mathrm{O}_{24} \cdot 4 \mathrm{H}_{2} \mathrm{O} 0.05, \mathrm{H}_{3} \mathrm{BO}_{3}$ $0.2, \mathrm{CuSO}_{4} \cdot 5 \mathrm{H}_{2} \mathrm{O}$ 0.01. The nutrient solution was adjusted to $\mathrm{pH} 5.0$ with $\mathrm{NaOH}$ or $\mathrm{HCl}$ and changed every $3 \mathrm{~d}$.

\section{Experimental treatments}

Prior to plaque deposition on the root surfaces, seedlings were firstly incubated in deionized water ( $\mathrm{pH}$ 5.5) for $12 \mathrm{~h}$ to minimize interference of other elements (especially phosphorus) with iron. Seedlings were then transplanted into nutrition solution containing $50 \mathrm{mg} \mathrm{l}^{-1}$ ferrous ion $\left(\mathrm{Fe}^{2+}\right.$ as $\mathrm{FeSO}_{4} \cdot 7 \mathrm{H}_{2} \mathrm{O}$ instead of the Fe-EDTA used in the pre-cultivation stage of the seedlings) but P-free nutrient solution (Fe50) for 2 days to induce the formation of iron plaque. Control seedlings were supplied with $\mathrm{Fe}-$ EDTA but P-free full nutrient solution to avoid Fe deficiency $(\mathrm{Fe} 0)$. Afterwards all the seedlings were grown in normal nutrient solution for $1 \mathrm{~d}$ and then the $\mathrm{Fe}$ pre-treated seedlings ( $\mathrm{Fe} 50$ and $\mathrm{Fe} 0$ ) were further split into two groups so that half were used for the Zn-Cd study (Zn-Cd experiment) and the other half for the $\mathrm{P}-\mathrm{Cd}$ study (P-Cd experiment). In the $\mathrm{Zn}-\mathrm{Cd}$ experiment, $\mathrm{Fe} 50$ and $\mathrm{Fe} 0$ seedlings were exposed to
$10 \mu \mathrm{mol} \mathrm{l}^{-1} \mathrm{Cd}\left(3 \mathrm{CdSO}_{4} \cdot 8 \mathrm{H}_{2} \mathrm{O}\right)$ in solution, either with (Zn10) or without (Zn0) $10 \mu \mathrm{mol} 1^{-1} \mathrm{Zn}$. In the $\mathrm{P}-\mathrm{Cd}$ experiment, seedlings were subjected to $10 \mu \mathrm{mol} \mathrm{l}^{-1} \mathrm{Cd}$ either with (P1) or without (P0) $1.0 \mathrm{mmol}^{-1} \mathrm{P}$. Speciation calculated using Visual MINTEQ 2.3 showed that $97.3 \%$ of $\mathrm{Cd}$ was in the form of $\mathrm{Cd}^{2+}$ and $2.7 \%$ was present as $\mathrm{CdHPO} 4$ (aqueous form), indicating that no precipitation of Cd-P had occurred in the solution. The Cd concentration was chosen to represent heavily polluted conditions. The zinc concentration was based on published data on the interactions of $\mathrm{Zn}$ and $\mathrm{Cd}$ which showed that a molar ratio of $\mathrm{Zn} / \mathrm{Cd}$ of $1: 1$ was a threshold value above which an antagonistic effect of Zn and Cd might occur (Girling and Peterson 1981; Green et al. 2001). The P concentration was based on Liu et al. (2004b). The duration of exposure to $\mathrm{Zn}$ or $\mathrm{P}$ was 2 days and the seedlings were then harvested. The total combination of the elements gave four treatments in each experiment: Fe0Zn0, Fe0Zn10, $\mathrm{Fe} 50 \mathrm{Zn} 0, \mathrm{Fe} 50 \mathrm{Zn} 10$ in the $\mathrm{Zn}-\mathrm{Cd}$ experiment and $\mathrm{Fe} 0 \mathrm{P} 0, \mathrm{Fe} 0 \mathrm{P} 1, \mathrm{Fe} 50 \mathrm{P} 0$ and Fe50P1 in the P-Cd experiment. Each treatment was set up in triplicate.

The experiments were carried out in a controlled growth chamber in the Department of Plant Nutrition, China Agricultural University, Beijing. The day/night regime was $14 / 10 \mathrm{~h}$, the average temperature regime was $25 / 20^{\circ} \mathrm{C}$ and the average photon flux density was 120-150 $\mu \mathrm{mol} \mathrm{m} \mathrm{m}^{-2} \mathrm{~s}^{-1}$.

Extraction and determination of $\mathrm{Fe}, \mathrm{Cd}, \mathrm{P}$ and $\mathrm{Zn}$ on root surfaces and in roots and shoots

At harvest seedlings were separated into shoots and roots and then rinsed three times with deionized water. Iron plaque on fresh root surfaces was extracted using a modified dithionite-citrate-bicarbonate (DCB) method (Taylor and Crowder 1983; Otte et al. 1989). Briefly, the entire root system of each seedling was incubated for $60 \mathrm{~min}$ at $25^{\circ} \mathrm{C}$ in $60 \mathrm{ml} 0.03 \mathrm{~mol} \mathrm{l} \mathrm{l}^{-1}$ sodium citrate $\left(\mathrm{Na}_{3} \mathrm{C}_{6} \mathrm{H}_{5} \mathrm{O}_{7} \cdot 2 \mathrm{H}_{2} \mathrm{O}\right)$ and $0.125 \mathrm{~mol} \mathrm{l}^{-1}$ sodium bicarbonate $\left(\mathrm{NaHCO}_{3}\right)$ with the addition of $1.2 \mathrm{~g}$ sodium dithionite $\left(\mathrm{Na}_{2} \mathrm{~S}_{2} \mathrm{O}_{4}\right)$. The extracts were transferred to $100-\mathrm{ml}$ glass flasks and filtered into plastic containers for analysis. Roots appeared completely white after extraction and no visible damage to the 
roots was observed. After DCB extraction of the roots, roots and shoots were oven dried at $70^{\circ} \mathrm{C}$ for 3 days and weighed.

Oven dried root and shoot samples were ground. Sub-samples (approximate $0.16 \mathrm{~g}$ roots and $0.30 \mathrm{~g}$ shoots) were weighed into digestion tubes and moistened overnight with $5 \mathrm{ml}$ mixed concentrated acid $\left(87 / 13 \quad \mathrm{HNO}_{3} / \mathrm{HClO}_{4}\right.$ by volume). On the following day the samples were heated on a digestion block at $90^{\circ} \mathrm{C}$ for $3 \mathrm{~h}$, then at $140^{\circ} \mathrm{C}$ for $5 \mathrm{~h}$, and $180^{\circ} \mathrm{C}$ for a further $2 \mathrm{~h}$ until little solution remained but without complete drying out. After cooling, the digests were transferred to $25-\mathrm{ml}$ flasks with deionized water and filtered into plastic bottles. A reagent blank and a standard reference material (tomato, GSB 07-12642000, Chinese National Certified Reference Material) were included to verify the accuracy and precision of the digestion procedure and subsequent analysis.

Elemental concentrations in the DCB extracts and in the acid digests were measured by inductively coupled plasma-optical emission spectrometry (ICP-OES, Optima 3300 DV, Perkin Elmer, USA). An internal standard was included and negligible matrix effects were observed. Total uptake of the elements and the distributions of the elements in DCB extracts and in roots and shoots were calculated according to Liu et al. (2004b).

\section{Statistical analysis}

Data from each of the two experiments were subjected to two-way analysis of variance using SAS for Windows (Version 8.2, SAS Institute, Cary, NC). Data presented are means $\pm \mathrm{SD}(n=3)$ and were compared by least significant difference (LSD) at the 5\% level.

\section{Results}

Appearance of iron plaque on root surfaces

The visual appearance of root surfaces differed greatly between the control and $\mathrm{Fe}^{2+}$ treated plants. Roots of plants subjected to $50 \mathrm{mg} \mathrm{l^{-1 }} \mathrm{Fe}^{2+}$ formed a deep orange color indicating the presence of iron plaque. The iron plaque was unevenly distributed and the color of the plaque became gradually darker towards the basal parts from $1 \mathrm{~cm}$ behind the root tips along the entire roots. Some root zones were heavily coated with
Table 1 Mean dry weights of shoots and roots of rice seedlings with $(\mathrm{Fe} 50)$ or without iron plaque $(\mathrm{Fe} 0)$ on root surfaces

\begin{tabular}{|c|c|c|c|}
\hline \multicolumn{2}{|l|}{ Treatment } & $\begin{array}{l}\text { Shoot dry weight } \\
(\mathrm{g})\end{array}$ & $\begin{array}{l}\text { Root dry weigh } \\
\text { (g) }\end{array}$ \\
\hline \multicolumn{4}{|c|}{$\mathrm{Zn}-\mathrm{Cd}$ experiment } \\
\hline \multirow[t]{2}{*}{$\mathrm{Fe} 0$} & $\mathrm{Zn} 0$ & $0.55 \pm 0.05$ & $0.18 \pm 0.02$ \\
\hline & $\mathrm{Zn} 10$ & $0.49 \pm 0.04$ & $0.15 \pm 0.02$ \\
\hline \multirow[t]{2}{*}{ Fe50 } & $\mathrm{Zn} 0$ & $0.39 \pm 0.00$ & $0.12 \pm 0.01$ \\
\hline & $\mathrm{Zn} 10$ & $0.45 \pm 0.01$ & $0.13 \pm 0.00$ \\
\hline \multicolumn{4}{|c|}{ Analysis of variance } \\
\hline & $\mathrm{Fe}$ & $P<0.001$ & $P<0.001$ \\
\hline & $\mathrm{Zn}$ & ns & ns \\
\hline & $\mathrm{Fe} \times \mathrm{Zn}$ & $P=0.006$ & $P=0.011$ \\
\hline \multicolumn{4}{|c|}{$\mathrm{P}-\mathrm{Cd}$ experiment } \\
\hline \multirow[t]{2}{*}{$\mathrm{Fe} 0$} & $\mathrm{P} 0$ & $0.49 \pm 0.03$ & $0.15 \pm 0.01$ \\
\hline & $\mathrm{P} 1$ & $0.58 \pm 0.05$ & $0.19 \pm 0.01$ \\
\hline \multirow[t]{2}{*}{$\mathrm{Fe} 50$} & $\mathrm{P} 0$ & $0.46 \pm 0.01$ & $0.14 \pm 0.01$ \\
\hline & $\mathrm{P} 1$ & $0.42 \pm 0.01$ & $0.13 \pm 0.01$ \\
\hline \multirow{3}{*}{$\begin{array}{l}\text { Analysis of } \\
\text { variance }\end{array}$} & $\mathrm{Fe}$ & $P=0.002$ & $P=0.001$ \\
\hline & $\mathrm{P}$ & ns & $\mathrm{ns}$ \\
\hline & $\mathrm{Fe} \times \mathrm{P}$ & $P=0.014$ & $P=0.008$ \\
\hline
\end{tabular}

Plants were exposed to $10 \mu \mathrm{mol}{ }^{-1} \mathrm{Cd}$ solution in the presence (Zn10) or absence $(\mathrm{Zn} 0)$ of $10 \mu \mathrm{mol} 1^{-1} \mathrm{Zn}(\mathrm{Zn}-\mathrm{Cd}$ experiment), or supplied with $1 \mathrm{mmol}^{-1} \mathrm{P}(\mathrm{P} 1)$ or without $\mathrm{P}$ (P0) (P-Cd experiment). The data were subjected to two-way analysis of variance. Data presented are means $\pm S D(n=3)$ ns, no significant difference

iron plaque while others were lightly smeared. Root surfaces of the control seedlings had a relatively evenly distributed orange color and the root tips remained white. The control seedlings formed a weak iron plaque on the root surfaces due to the supply of $\mathrm{Fe}-$ EDTA during the pre-cultivation seedling stage.

Dry weights of shoots and roots

Seedling shoot and root dry weights were significantly affected by $\mathrm{Fe}$ additions and $\mathrm{Fe} \times \mathrm{Zn}$ or $\mathrm{Fe} \times \mathrm{P} \quad(P<0.05)$ interactions, but not by $\mathrm{Zn}$ or $\mathrm{P}$ additions in the nutrient solution (Table 1). The shoot and root dry weights of seedlings treated with $\mathrm{Fe}$ were significantly lower than of seedlings without $\mathrm{Fe}^{2+}$ in both experiments (Table 1). Zn supply significantly increased shoot and root dry weights at Fe50. At Fe50, shoot dry weights at P1 were significantly lower than at P0, while root dry weights at P1 were significantly higher than at P0 when no $\mathrm{Fe}$ was supplied (Table 1). A general trend was that shoot and root dry weights 
Table 2 Iron concentrations $\left(\mathrm{g} \mathrm{kg}^{-1}\right.$ root dry matter) in dithionite-citrate-bicarbonate (DCB) extracts of the root surface and in roots and shoots of rice seedlings with (Fe50) or without $(\mathrm{Fe} 0)$ iron plaque in the $\mathrm{Zn}-\mathrm{Cd}$ and $\mathrm{P}-\mathrm{Cd}$ experiments

Fe in shoots $\mathrm{Fe}$ in roots $\mathrm{Fe}$ in DCB $\left(\mathrm{g} \mathrm{kg}^{-1} \mathrm{DM}\right) \quad\left(\mathrm{g} \mathrm{kg}^{-1} \mathrm{DM}\right) \quad\left(\mathrm{g} \mathrm{kg}^{-1} \mathrm{DM}\right.$ roots$)$

$\mathrm{Zn}-\mathrm{Cd}$ experiment

$\begin{array}{lllll}\mathrm{Fe} 0 & \mathrm{Zn} 0 & 0.40 \pm 0.03 & 0.54 \pm 0.06 & 8.28 \pm 1.17 \\ & \mathrm{Zn} 10 & 0.39 \pm 0.02 & 0.51 \pm 0.04 & 10.68 \pm 3.12 \\ \mathrm{Fe} 50 & \mathrm{Zn} 0 & 0.70 \pm 0.08 & 1.74 \pm 0.05 & 45.91 \pm 6.57 \\ & \mathrm{Zn} 10 & 0.71 \pm 0.11 & 1.49 \pm 0.08 & 48.55 \pm 12.34\end{array}$

Analysis of variance

$\begin{array}{llll}\mathrm{Fe} & P<0.001 & P<0.001 & P<0.001 \\ \mathrm{Zn} & \mathrm{ns} & P=0.011 & \text { ns } \\ \mathrm{Fe} \times \mathrm{Zn} & \mathrm{ns} & P=0.030 & \text { ns }\end{array}$

$\mathrm{P}-\mathrm{Cd}$ experiment

$\begin{array}{lllll}\text { Fe0 } & \text { P0 } & 0.36 \pm 0.02 & 0.56 \pm 0.04 & 10.06 \pm 1.24 \\ & \text { P1 } & 0.49 \pm 0.06 & 0.75 \pm 0.02 & 7.82 \pm 0.71 \\ \text { Fe50 } & \text { P0 } & 0.48 \pm 0.06 & 1.79 \pm 0.20 & 56.19 \pm 4.57 \\ & \text { P1 } & 0.63 \pm 0.09 & 2.03 \pm 0.14 & 56.37 \pm 1.02\end{array}$

Analysis of variance

$\begin{array}{llll}\mathrm{Fe} & P=0.006 & P<0.001 & P<0.001 \\ \mathrm{P} & P=0.008 & P=0.028 & \text { ns } \\ \mathrm{Fe} \times \mathrm{P} & \mathrm{ns} & \text { ns } & \text { ns }\end{array}$

Data are means \pm SD $(n=3)$

Fig. 1 Cadmium concentrations in dithionite-citratebicarbonate (DCB) extracts and in roots and shoots of rice seedlings with $(\mathrm{Fe} 50)$ or without $(\mathrm{FeO})$ iron plaque on root surfaces in the $\mathrm{Zn}$ $\mathrm{Cd}$ and $\mathrm{P}-\mathrm{Cd}$ experiments. Error bars: \pm SD. Lower case $a$ and $b$ indicate significant differences between the two $\mathrm{Zn}$ or P supply levels at $\mathrm{Fe} 50$ or $\mathrm{Fe} 0$ appeared to be depressed by $\mathrm{Zn}$ supply at $\mathrm{Fe} 0$, but increased at Fe50, but $\mathrm{P}$ supply showed the opposite trend.

Fe concentrations in DCB extracts, roots and shoots

Iron concentrations in DCB extracts and in roots and shoots of rice seedlings were significantly increased by Fe supply $(P<0.01)$ and the effect was significantly higher at $\mathrm{Fe} 50$ than at $\mathrm{Fe} 0$ (Table 2). Zn supply had no significant effect on Fe concentrations except that the mean root $\mathrm{Fe}$ concentration at $\mathrm{Fe} 50$ was lower at $\mathrm{Zn} 10$ than at $\mathrm{Zn} 0$. At $\mathrm{Fe} 0, \mathrm{Fe}$ concentrations in shoots and roots at P1 were significantly higher than at P0, and at Fe50, P supply had no significant effect on shoot or root $\mathrm{Fe}$ concentrations.

Cd concentrations in DCB extracts, roots and shoots

Irrespective of $\mathrm{Zn}$ or $\mathrm{P}$ supply levels, $\mathrm{Cd}$ concentrations in DCB extracts were significantly higher at $\mathrm{Fe} 50$ than at $\mathrm{Fe} 0$, and in contrast, root and shoot $\mathrm{Cd}$ concentrations at $\mathrm{Fe} 50$ were lower than at $\mathrm{Fe} 0$ and the effect was more pronounced in the $\mathrm{P}-\mathrm{Cd}$ experiment. $\mathrm{Zn}$ supply in the nutrient solution significantly decreased root $\mathrm{Cd}$ concentrations and increased shoot
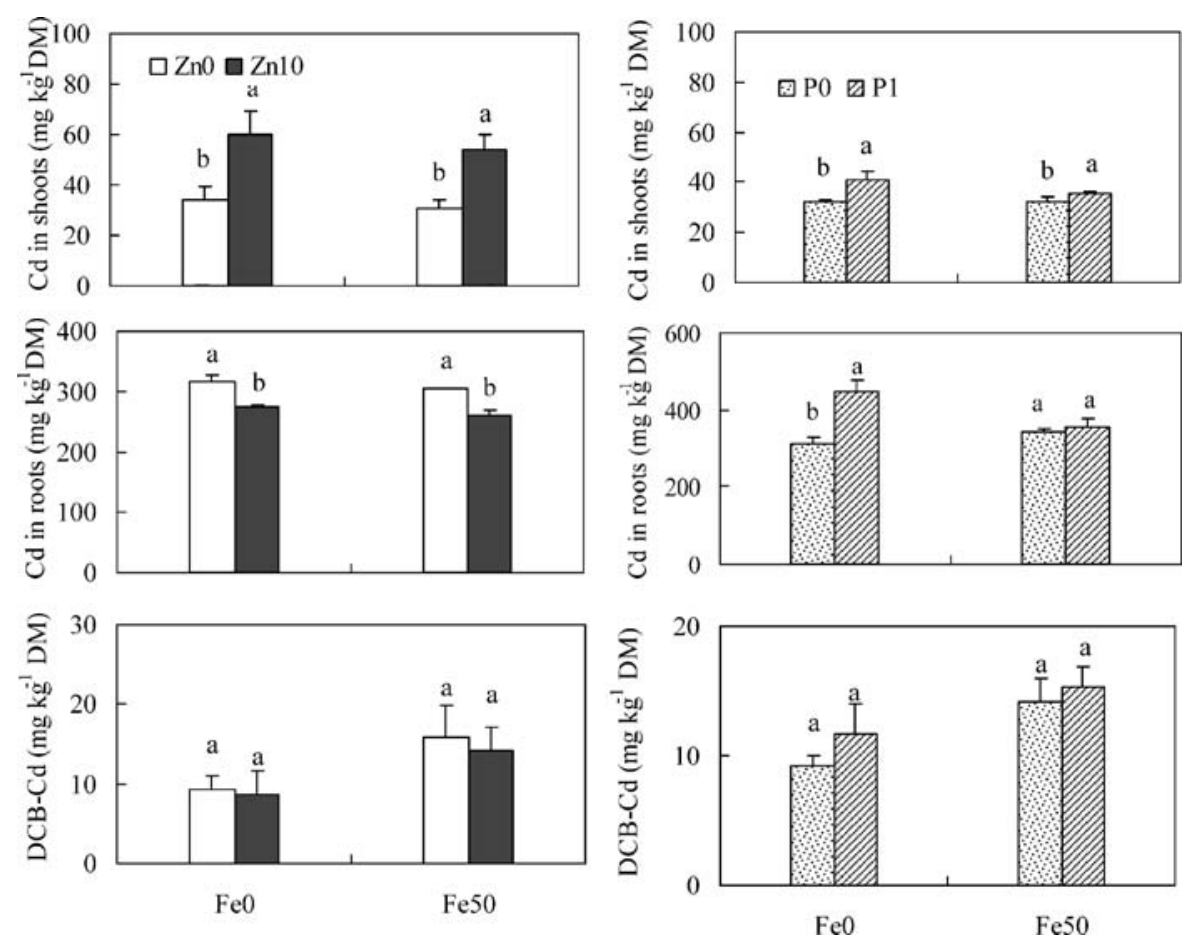
Table 3 Two-way analysis of variance of Cd concentrations in dithionite-citrate-bicarbonate (DCB) extracts and in roots and shoots of rice seedlings shown in Fig. 1

\begin{tabular}{|c|c|c|c|c|c|c|c|}
\hline & \multicolumn{4}{|c|}{$\mathrm{Zn}-\mathrm{Cd}$ experiment } & \multicolumn{3}{|c|}{$\mathrm{P}-\mathrm{Cd}$ experiment } \\
\hline & $\mathrm{Cd}$ in shoots & $\mathrm{Cd}$ in roots & $\mathrm{Cd}$ in $\mathrm{DCB}$ & & $\mathrm{Cd}$ in shoots & $\mathrm{Cd}$ in roots & $\mathrm{Cd}$ in $\mathrm{DCB}$ \\
\hline $\mathrm{Fe}$ & ns & $P=0.014$ & $P=0.020$ & $\mathrm{Fe}$ & $P=0.049$ & $P=0.040$ & $P=0.008$ \\
\hline $\mathrm{Zn}$ & $P<0.001$ & $P<0.001$ & $\mathrm{~ns}$ & $\mathrm{P}$ & $P<0.001$ & $P<0.001$ & ns \\
\hline $\mathrm{Fe} \times \mathrm{Zn}$ & ns & $\mathrm{ns}$ & ns & $\mathrm{Fe} \times \mathrm{P}$ & $P=0.045$ & $P=0.002$ & ns \\
\hline
\end{tabular}

$\mathrm{Cd}$ concentrations at both $\mathrm{Fe}$ supply levels. In comparison, $\mathrm{P}$ supply significantly increased root and shoot $\mathrm{Cd}$ concentrations at $\mathrm{Fe} 0$, and at $\mathrm{Fe} 50$ the increments of shoot and root $\mathrm{Cd}$ concentrations between P1 and P0 were smaller as shown by the significant interaction between $\mathrm{Fe}$ and $\mathrm{P}$ supply (Fig. 1, Table 3).

$\mathrm{Zn}$ and $\mathrm{P}$ concentrations in DCB extracts, roots and shoots

Zinc concentrations in DCB extracts and roots were significantly higher at $\mathrm{Fe} 50$ than at $\mathrm{Fe} 0$, while no significant difference was observed in shoot $\mathrm{Zn}$ concentration between the two Fe treatments (Fig. 2, Table 4). P concentrations in DCB extracts and shoots at $\mathrm{Fe} 50$ were also higher than at $\mathrm{Fe} 0$, while root $\mathrm{P}$ concentrations showed the reverse trend. Zn concentrations in DCB extracts and in roots and shoots were significantly higher at $\mathrm{Zn} 10$ than at $\mathrm{Zn} 0$. External $\mathrm{P}$ supply had no significant effect on DCB-P or shoot $\mathrm{P}$ concentrations, while root $\mathrm{P}$ concentrations were higher at $\mathrm{P} 1$ than at $\mathrm{P} 0$. The difference in root $\mathrm{P}$ concentrations between the two $\mathrm{P}$ levels was more pronounced at $\mathrm{Fe} 0$ than at $\mathrm{Fe} 50$ as indicated by the $\mathrm{Fe}$ and $\mathrm{P}$ interactions on root $\mathrm{P}$ concentrations $(P<0.001)$.
Fig. 2 Zinc and $\mathrm{P}$ concentrations in dithionitecitrate-bicarbonate (DCB) extracts and in roots and shoots of rice seedlings with $(\mathrm{Fe} 50)$ or without $\mathrm{FeO})$ iron plaque on root surfaces in the $\mathrm{Zn}-\mathrm{Cd}$ and $\mathrm{P}-\mathrm{Cd}$ experiments. Error bars: \pm SD. Lower case $a$ and $b$ indicate significant differences between the two $\mathrm{Zn}$ or $\mathrm{P}$ supply levels at $\mathrm{Fe} 50$ or $\mathrm{Fe} 0$
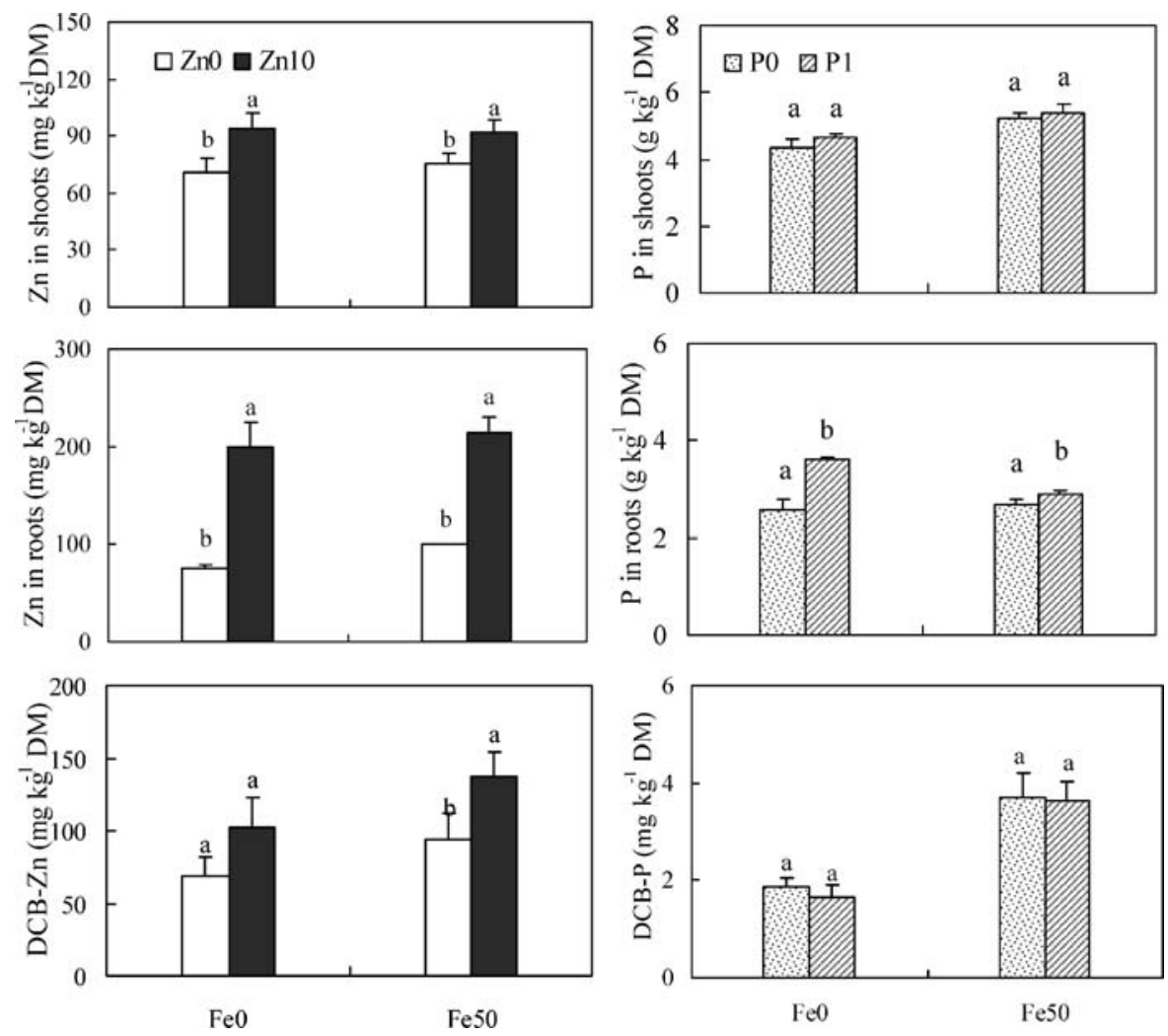
Table 4 Two-way analysis of variance of $\mathrm{Zn}$ and $\mathrm{P}$ concentrations in dithionite-citrate-bicarbonate (DCB) extracts and in roots and shoots of rice seedlings shown in Fig. 2

\begin{tabular}{|c|c|c|c|c|c|c|c|}
\hline & \multicolumn{3}{|c|}{$\mathrm{Zn}-\mathrm{Cd}$ experiment } & & \multicolumn{3}{|c|}{$\mathrm{P}-\mathrm{Cd}$ experiment } \\
\hline & $\mathrm{Zn}$ in shoots & $\mathrm{Zn}$ in roots & $\mathrm{Zn}$ in $\mathrm{DCB}$ & & $\mathrm{P}$ in shoots & $\mathrm{P}$ in roots & $\mathrm{P}$ in $\mathrm{DCB}$ \\
\hline $\mathrm{Fe}$ & ns & $P=0.048$ & $P=0.031$ & $\mathrm{Fe}$ & $P<0.001$ & $P=0.003$ & $P<0.001$ \\
\hline $\mathrm{Zn}$ & $P=0.003$ & $P<0.001$ & $P=0.011$ & $\mathrm{P}$ & $\mathrm{ns}$ & $P<0.001$ & ns \\
\hline $\mathrm{Fe} \times \mathrm{Zn}$ & ns & ns & ns & $\mathrm{Fe} \times \mathrm{P}$ & ns & $P<0.001$ & ns \\
\hline
\end{tabular}

Distribution of $\mathrm{Cd}, \mathrm{P}$ and $\mathrm{Zn}$ in $\mathrm{DCB}$ extracts, roots and shoots

In both experiments the percentages of $\mathrm{Cd}$ in $\mathrm{DCB}$ extracts were significantly lower than in roots or shoots, accounting for up to approximately $1.8-3.8 \%$ of plant total $\mathrm{Cd}$ (Table 5). In contrast, the percentages of $\mathrm{Cd}$ in roots and shoots were up to around $57-73 \%$ and $23-40 \%$ respectively in the $\mathrm{Zn}-\mathrm{Cd}$ experiment. The corresponding values in the $\mathrm{P}-\mathrm{Cd}$ experiment were $73-76 \%$ and $21-24 \%$. In both experiments DCB$\mathrm{Cd}$ percentage was significantly higher at $\mathrm{Fe} 50$ than at $\mathrm{Fe} 0$. The percentages of $\mathrm{Cd}$ in roots and shoots were significantly affected by $\mathrm{Zn}$ supply in the $\mathrm{Zn}-\mathrm{Cd}$ experiment (Table 5). At $\mathrm{Fe} 0$ shoot and root percentages were lower when $\mathrm{Zn}$ was supplied and the reverse was observed at Fe50. However, P supply had no significant effect on root $\mathrm{Cd}$ or shoot $\mathrm{Cd}$ percentage.

The percentages of $\mathrm{Zn}$ and $\mathrm{P}$ in shoots were much higher than in roots and DCB extracts, accounting for about $46-60 \%$ and $72-76 \%$ respectively of plant $\mathrm{Zn}$ and $\mathrm{P}$ uptake (Table 6). Fe supply had no significant effect on $\mathrm{Zn}$ distribution in different plant parts in the
$\mathrm{Zn}-\mathrm{Cd}$ experiment, but in the $\mathrm{P}-\mathrm{Cd}$ experiment $\mathrm{Fe}$ supply increased DCB-P, decreased root $\mathrm{P}$ but showed no significant effect on shoot $\mathrm{P}$ percentage.

\section{Discussion}

The amounts of iron plaque on the root surfaces of rice were approximately $8-10 \mathrm{~g} \mathrm{~kg}^{-1}$ at $\mathrm{Fe} 0$ and $45-$ $48 \mathrm{~g} \mathrm{~kg}^{-1}$ at Fe50, which fell within the range (the lowest $\sim 0.15 \mathrm{~g} \mathrm{~kg}^{-1}$ and the highest $\sim 59 \mathrm{~g} \mathrm{~kg}^{-1}$ ) reported for other wetland plants (St-Cyr and Crowder 1989; Hansel et al. 2002) and rice ( 25-102 $\mathrm{g} \mathrm{kg}^{-1}$, Chen et al. 1980b) in the field. Uptake of nutrient elements and/or metal(loids) can be mediated by the formation of ion plaque on root surfaces of wetland and some terrestrial plants. However, the effects of iron plaque on plant elemental uptake are controversial. Some workers have suggested that iron plaque can sequester metal(loid)s such as $\mathrm{Al}$ and $\mathrm{As}$ on root surfaces of rice and thus depress their translocation to the shoots (Batty et al. 2000; Chen et al. 2006; Greipsson 1994, 1995; Liu et al. 2004b). Others have shown that iron plaque has little effect on Cd uptake

Table 5 Distribution of $\mathrm{Cd}$ in rice: percentages of $\mathrm{Cd}$ in dithionite-citrate-bicarbonate (DCB) extracts, roots and shoots of rice seedlings with $(\mathrm{Fe} 50)$ or without $(\mathrm{Fe} 0)$ iron plaque on root surfaces in the $\mathrm{Zn}-\mathrm{Cd}$ and $\mathrm{P}-\mathrm{Cd}$ experiments

\begin{tabular}{|c|c|c|c|c|c|c|c|c|}
\hline \multicolumn{6}{|c|}{$\mathrm{Zn}-\mathrm{Cd}$ experiment } & \multicolumn{3}{|c|}{$\mathrm{P}-\mathrm{Cd}$ experiment } \\
\hline \multicolumn{2}{|c|}{ Treatment } & \multirow{2}{*}{$\frac{\text { Shoot Cd \% }}{24.6 \pm 1.99}$} & \multirow{2}{*}{$\begin{array}{c}\text { Root Cd \% } \\
73.2 \pm 2.23\end{array}$} & \multirow{2}{*}{$\begin{array}{c}\mathrm{DCB}-\mathrm{Cd} \% \\
2.15 \pm 0.27\end{array}$} & \multirow{2}{*}{$\begin{array}{l}\text { Treatment } \\
\text { P0 }\end{array}$} & \multirow{2}{*}{$\begin{array}{l}\text { Shoot Cd \% } \\
24.2 \pm 0.64\end{array}$} & \multirow{2}{*}{$\begin{array}{l}\text { Root Cd \% } \\
73.7 \pm 0.57\end{array}$} & \multirow{2}{*}{$\frac{\mathrm{DCB}-\mathrm{Cd} \%}{2.18 \pm 0.08}$} \\
\hline $\mathrm{Fe} 0$ & $\mathrm{Zn} 0$ & & & & & & & \\
\hline & $\mathrm{Zn} 10$ & $40.4 \pm 4.16$ & $57.8 \pm 4.32$ & $1.83 \pm 0.55$ & $\mathrm{P} 1$ & $21.4 \pm 0.26$ & $76.5 \pm 0.21$ & $2.00 \pm 0.33$ \\
\hline \multirow[t]{2}{*}{ Fe50 } & $\mathrm{Zn} 0$ & $23.9 \pm 0.44$ & $72.3 \pm 1.29$ & $3.77 \pm 0.86$ & $\mathrm{P} 0$ & $22.4 \pm 0.75$ & $74.5 \pm 1.07$ & $3.07 \pm 0.35$ \\
\hline & $\mathrm{Zn} 10$ & $39.3 \pm 2.46$ & $57.5 \pm 1.79$ & $3.15 \pm 0.78$ & $\mathrm{P} 1$ & $23.6 \pm 1.29$ & $73.3 \pm 1.04$ & $3.16 \pm 0.26$ \\
\hline \multicolumn{9}{|c|}{ Analysis of variance } \\
\hline $\mathrm{Fe}$ & & $\mathrm{ns}$ & ns & $P=0.015$ & $\mathrm{Fe}$ & ns & $P=0.050$ & $P=0.001$ \\
\hline $\mathrm{Zn}$ & & $P<0.001$ & $P<0.001$ & ns & $\mathrm{P}$ & ns & ns & ns \\
\hline $\mathrm{Fe} \times$ & & ns & ns & ns & $\mathrm{Fe} \times \mathrm{P}$ & $P=0.008$ & $P=0.006$ & ns \\
\hline
\end{tabular}

Data are means \pm SD $(n=3)$ 
Table 6 Distributions of $\mathrm{Zn}$ and $\mathrm{P}$ in rice: percentages of $\mathrm{Zn}$ and $\mathrm{P}$ in dithionite-citrate-bicarbonate (DCB) extracts, roots and shoots of rice seedlings with $(\mathrm{Fe} 50)$ or without $(\mathrm{Fe} 0)$ iron plaque on root surfaces in $\mathrm{Zn}-\mathrm{Cd}$ and $\mathrm{P}-\mathrm{Cd}$ experiments

\begin{tabular}{|c|c|c|c|c|c|c|c|c|c|}
\hline \multicolumn{2}{|c|}{ Treatments } & \multicolumn{3}{|c|}{$\mathrm{Zn}-\mathrm{Cd}$ experiment } & \multirow{2}{*}{\multicolumn{2}{|c|}{ Treatments }} & \multicolumn{3}{|c|}{$\mathrm{P}-\mathrm{Cd}$ experiment } \\
\hline & & \multirow{2}{*}{$\begin{array}{c}\text { Shoot } \mathrm{Zn} \% \\
60.1 \pm 2.18\end{array}$} & \multirow{2}{*}{$\frac{\text { Root } \mathrm{Zn} \%}{21.2 \pm 2.73}$} & \multirow{2}{*}{$\frac{\mathrm{DCB}-\mathrm{Zn} \%}{18.7 \pm 0.55}$} & & & \multirow{2}{*}{$\frac{\text { Shoot P\% }}{75.6 \pm 1.73}$} & \multirow{2}{*}{$\begin{array}{l}\text { Root } \mathrm{P} \% \\
14.1 \pm 0.99\end{array}$} & \multirow{2}{*}{$\frac{\mathrm{DCB}-\mathrm{P} \%}{10.3 \pm 1.55}$} \\
\hline $\mathrm{Fe} 0$ & $\mathrm{Zn} 0$ & & & & $\mathrm{Fe} 0$ & $\mathrm{P} 0$ & & & \\
\hline & $\mathrm{Zn} 10$ & $50.0 \pm 1.74$ & $32.9 \pm 3.10$ & $17.1 \pm 3.96$ & & $\mathrm{P} 1$ & $73.2 \pm 0.82$ & $18.4 \pm 0.44$ & $8.48 \pm 1.12$ \\
\hline & $\mathrm{Zn} 0$ & $56.2 \pm 2.91$ & $22.7 \pm 1.41$ & $21.1 \pm 3.35$ & $\mathrm{Fe} 50$ & $\mathrm{P} 0$ & $72.5 \pm 1.48$ & $11.6 \pm 0.29$ & $15.9 \pm 1.55$ \\
\hline & $\mathrm{Zn} 10$ & $46.7 \pm 4.33$ & $32.4 \pm 2.05$ & $20.9 \pm 2.32$ & & $\mathrm{P} 1$ & $72.5 \pm 1.55$ & $12.1 \pm 0.16$ & $15.4 \pm 1.43$ \\
\hline \multicolumn{10}{|c|}{ Analysis of variance } \\
\hline $\mathrm{Fe}$ & & $\mathrm{ns}$ & $\mathrm{ns}$ & $\mathrm{ns}$ & $\mathrm{Fe}$ & & ns & $P<0.001$ & $P<0.001$ \\
\hline $\mathrm{Zn}$ & & $P=0.002$ & $P<0.001$ & ns & $\mathrm{P}$ & & ns & $P<0.001$ & ns \\
\hline $\mathrm{Fe} \times$ & & ns & ns & ns & $\mathrm{Fe} \times \mathrm{P}$ & & $\mathrm{ns}$ & $P=0.002$ & ns \\
\hline
\end{tabular}

Data are means \pm SD $(n=3)$

(Liu et al. 2007), and some have demonstrated that iron plaque can act as a $\mathrm{P}$ reservoir to enhance plant $\mathrm{P}$ uptake (Liang et al. 2006; Zhang et al. 1999). In the present study the distribution of Cd in DCB extracts (about 1.8-3.8\%) was minor when compared to the proportions of $\mathrm{Cd}$ in the roots $(\sim 57-76 \%)$ and shoots ( $\sim 21-40 \%$, Table 5), and this was in marked contrast to the distribution of other anions (Liu et al. 2004a,b; Zhou et al. 2007) where DCB\% accounted for the major proportions of the elements. Although the $\mathrm{Cd}$ concentrations in DCB extracts increased in Fetreated plants, $\mathrm{Cd}$ concentrations in roots and shoots decreased significantly (except shoot $\mathrm{Cd}$ concentrations in the $\mathrm{Zn}-\mathrm{Cd}$ experiment, Fig. 1), and the present study indicates that the contribution of iron plaque to plant $\mathrm{Cd}$ uptake was minor and the roots may have been the main tissue acting as a barrier to plant Cd uptake. These results differ from others (Chen et al. 2006; Batty et al. 2000; Greipsson 1994, 1995; Liu et al. 2004b) but agree with our conclusions (Liu et al. 2007) and those of Liu et al. (2005) who also found that root tissue was the main barrier to As uptake by rice plants when arsenite was supplied. Similar results were also reported for metal uptake by other wetland plants, for example $\mathrm{Pb}$ and $\mathrm{Cd}$ uptake by Typha latifolia (Ye et al. 1998), $\mathrm{Cu}, \mathrm{Zn}$ and $\mathrm{Pb}$ uptake by water hyacinth (Vesk et al. 1999), and Fe, $\mathrm{Mn}, \mathrm{Cu}$ and $\mathrm{Zn}$ uptake by Juncus bulbosus (Chabbi 1999). The increase in Fe nutritional level in plants may partially alleviate the potential toxic effects of $\mathrm{Cd}$ to plant growth, as shown by the decreased $\mathrm{Cd}$ concentrations in roots and shoots at $\mathrm{Fe} 50$ than at $\mathrm{Fe} 0$ in both experiments (Fig. 1). Fe has been shown to exert strong competition over other heavy metals for sensitive metabolic sites within the leaves (Kuo 1986; Taylor and Crowder 1983) or in the root tips (Chen et al. 2006). Mean shoot Fe concentrations in the present experiment at Fe50 (except at P0) were higher than the $448 \mathrm{mg} \mathrm{kg}^{-1}$ reported for normally grown rice plants (Ottow et al. 1982). However, no visible $\mathrm{Fe}$ toxicity symptoms were observed even though root dry weight decreased at Fe50 (Table 1), indicating that roots were more sensitive to the external Fe supply. In the literature, decreases (Ye et al. 2001; Liu et al. 2007) or increases (Greipsson and Crowder 1992; Greipsson 1994, 1995) or no changes in root dry weight have been reported in response to pre-treatment to induce the formation of iron plaque on root surfaces.

The distributions of $\mathrm{P}$ and $\mathrm{Zn}$ in different plant parts were in contrast with that of Cd (Fig. 2, Table 6). The proportions of $\mathrm{Zn}$ and $\mathrm{P}$ in shoots were much higher than in roots and DCB extracts, accounting for approximately 46-60\% (Zn-Cd experiment) and 72$76 \%$ (P-Cd experiment) respectively of plant $\mathrm{Zn}$ and $\mathrm{P}$ uptake. Since $\mathrm{P}$ and $\mathrm{Zn}$ are essential elements for plant growth under our experimental conditions in which $\mathrm{P}$ and $\mathrm{Zn}$ concentrations were not high but shoot $\mathrm{Cd}$ concentrations were high, rice may have evolved mechanisms to increase plant uptake and translocation of $\mathrm{Zn}$ and P. For example, Zhang et al. (1998) found that phytosiderophores released by Fedeficient plants enhanced $\mathrm{Zn}$ uptake by rice plants with iron plaque up to a particular amount of $\mathrm{Fe}$, and enhanced shoot $\mathrm{P}$ uptake was assumed to be related to substances other than siderophores released by plants (Zhang et al. 1999). The overall role of iron plaque in elemental uptake by rice may vary among studies 
according to differences in culture methodology, duration of the treatments, the element or contaminant studied, or the amount of iron plaque on the root surfaces (Zhang et al. 1998; Otte et al. 1989), plant genotypes (Liu et al. 2004a) and to the status of nutrients such as P (Liu et al. 2004b) and Fe (Zhang et al. 1998). The present study and others highlight the complexity of transport of nutrient elements and/ or metal(loids) from soil to rice shoots via the soilrhizosphere-iron plaque-root-shoot circuit.

Neither Zn nor P addition had any significant effect on $\mathrm{Cd}$ concentrations in $\mathrm{DCB}$ extracts while $\mathrm{Cd}$ concentrations in roots and shoots were significantly affected. This indicates that iron plaque on the root surfaces may not be the site where $\mathrm{Zn}$ and $\mathrm{P}$ affect $\mathrm{Cd}$ adsorption and uptake by and translocation within rice seedlings. This leads us to deviate partly from our initial hypothesis but may be explained by the minor role of iron plaque in plant Cd uptake. Studies on the deposition and distribution patterns of elements on iron plaque by means of in situ techniques such as scanning electron microscopy (SEM) analysis may help to provide further evidence to support our conclusions. Providing that small amounts of $\mathrm{Cd}$ are present in iron plaque, it is understandable that $\mathrm{Zn}$ or $\mathrm{P}$ may have little effect on $\mathrm{Cd}$ adsorption since the codepositon of large amounts of other elements such as $\mathrm{P}$ and $\mathrm{Zn}$ and/or precipitates (in the case of $\mathrm{P}$ ) may mask any effects of $\mathrm{Cd}$. Few experiments reported in the literature have studied the effects of accompanying ions on elemental uptake by plants with iron plaque. Batty et al. (2000) combined solution culture with SEM to study the effects of iron plaque on root surfaces of Phragmites australis on plant $\mathrm{Mn}$ and $\mathrm{Cu}$ uptake. The solution culture work showed that adsorption of $\mathrm{Cu}$ and $\mathrm{Mn}$ on the plaque was affected by the $\mathrm{pH}$ value of the solution. At $\mathrm{pH} 6.0$ shoot $\mathrm{Cu}$ concentrations were lower in the presence than in the absence of plaque while at $\mathrm{pH} 3.5$ the potential effect of iron plaque was masked by activity of hydrogen ions. However, based on SEM analysis of both field and laboratory specimens, they suggested that iron plaque may have an extremely limited capacity to adsorb metals such as $\mathrm{Mn}$ or $\mathrm{Cu}$. Kuo (1986) found that the adsorption of $\mathrm{P}$ by a synthetic hydrous $\mathrm{Fe}$ oxide did not affect $\mathrm{Cd}, \mathrm{Ca}$ or $\mathrm{Zn}$ sorption. In contrast, Geng et al. (2005) provided evidence that external $\mathrm{P}$ concentrations affect As uptake and translocation in rice seedlings. The effect was attributed to an interaction among plant $\mathrm{P}$ nutrition, the formation of iron plaque on root surfaces, and As sequestration in iron plaque, indicating a possible indirect effect of external $\mathrm{P}$ supply on As uptake by plants although the direct competition of $\mathrm{P}$ on As uptake could not be fully excluded.

The decreased $\mathrm{Cd}$ concentrations in roots and increased $\mathrm{Cd}$ concentrations in shoots of plants with or without iron plaque (Fig. 1, Table 3) indicate that $\mathrm{Zn}$ may have inhibited root $\mathrm{Cd}$ uptake but not the transfer of $\mathrm{Cd}$ from roots to shoots. An antagonistic effect of $\mathrm{Zn}$ on $\mathrm{Cd}$ uptake has been reported from numerous studies and the effect may be due to strong competition between $\mathrm{Zn}$ and $\mathrm{Cd}$ uptake because of the chemical similarity of the two elements (Hart et al. 2005; White and Chaney 1980). Recently Hassan et al. (2005) showed that at high Cd supply $\left(5 \mu \mathrm{mol} \mathrm{l}^{-1}\right.$ $\mathrm{Cd}$ compared to $1 \mu \mathrm{mol} \mathrm{l}^{-1} \mathrm{Cd}$ or without $\left.\mathrm{Cd}\right), \mathrm{Zn}$ (1.0 $\mu \mathrm{mol} \mathrm{l}^{-1}$ ) significantly increased shoot $\mathrm{Cd}$ concentrations but reduced root $\mathrm{Cd}$ concentrations. Kukier and Chaney (2002) found that at high external Cd levels (2.56 and $\left.4.55 \mu \mathrm{mol}{ }^{-1} \mathrm{Cd}\right), \mathrm{Zn}(3.89 \mu \mathrm{mol}$ $\left.1^{-1}\right)$ significantly stimulated $\mathrm{Cd}$ translocation from roots to shoots in rice plants at later growth stages.

Our results also indicate that there is an interaction between $\mathrm{P}$ supply and $\mathrm{Cd}$ uptake by rice plants (Fig. 1, Table 3). P additions in the solution substantially enhanced the $\mathrm{Cd}$ concentrations in roots and shoots when no Fe was supplied and P and Cd showed a synergistic interaction. Moral et al. (1994) reported that $\mathrm{P}$ concentrations in roots, stems, leaves and fruits of tomato plants supplied with $30 \mathrm{mg}^{-1} \mathrm{Cd}$ were higher than when supplied with 10 or $0 \mathrm{mg}^{-1} \mathrm{Cd}$. Lagriffoul et al. (1998) also found that $\mathrm{P}$ concentrations in maize leaves increased significantly when the $\mathrm{Cd}$ supply was over $5 \mu \mathrm{mol} \mathrm{l}^{-1}\left(0.56 \mathrm{mg} \mathrm{l}^{-1}\right)$. In the present study the synergistic effect of $\mathrm{P}$ on $\mathrm{Cd}$ uptake was diminished when Fe was supplied (50 $\mathrm{mg}^{-1}$ ), suggesting a possible three-factor interaction among Fe supply, $\mathrm{P}$ supply and Cd uptake. The mechanism by which Fe supply mediates the effect of $\mathrm{P}$ supply on $\mathrm{Cd}$ uptake requires further investigation.

In conclusion, our results suggest that rather than iron plaque, root tissue may be the main barrier to $\mathrm{Cd}$ uptake by rice plants. The adsorption of $\mathrm{Cd}$ on iron plaque is not affected by the external $\mathrm{Zn}$ or P supply. The uptake by and translocation of $\mathrm{Cd}$ in plants may be mediated by external $\mathrm{P}$ and $\mathrm{Zn}$ supply levels. $\mathrm{Zn}$ and $\mathrm{P}$ additions increased shoot $\mathrm{Cd}$ concentrations. 
Conventional agricultural practices to increase rice yields such as $\mathrm{P}$ fertilizer application may pose a potential risk of higher Cd uptake by rice plants from contaminated soils. However, high Fe concentrations in plants may help, to some extent, to minimize additional Cd uptake by plants.

Acknowledgements The study was supported by the Program for Innovative Research Teams in Universities of the Chinese Ministry of Education (Grant IRT0511) and the British Council with the UK Department for International Development through their Development Partnerships in Higher Education program (Project DelPHE 64). We thank Dr Shihua Lu, Institute of Soils and Fertilizers, Sichuan Academy of Agriculture Sciences, for supplying the rice seeds and two anonymous reviewers for helpful suggestions that greatly improved the manuscript.

\section{References}

Armstrong W (1967) The oxidizing activity of roots in waterlogged soils. Physiol Plant 20:920-926

Batty LC, Baker AJM, Wheeler BD, Curtis CD (2000) The effect of $\mathrm{pH}$ and plaque on the uptake of $\mathrm{Cu}$ and $\mathrm{Mn}$ in Phragmites australis (Cav.) Trin ex. Steudel. Ann Bot 86:647-653

Chabbi A (1999) Juncus bulbosus as a pioneer species in acidic lignite mining lakes: Interactions, mechanism and survival strategies. New Phytol 144:133-142

Chaney RL, Hornick SB (1978) Accumulation and effects of cadmium on crops. In Cadmium 77: Proc 1st Int. Cadmium Conf. San Francisco, Metal Bulletin Ltd, London, pp 125-140

Chen CC, Dixon JB, Turner FT (1980a) Iron coatings on rice roots: Mineralogy and quantity influencing factors. Soil Sci Soc Am J 44:635-639

Chen CC, Dixon JB, Turner FT (1980b) Iron coatings on rice roots: Morphology and models of development. Soil Sci Soc Am J 44, 1113-1119

Chen RF, Shen RF, Gu P, Dong XY, Du CW, Ma JF (2006) Response of rice (Oryza sativa) with root surface iron plaque under aluminium stress. Ann Bot 98:389-395

Geng CN, Zhu YG, Liu WJ, Smith SE (2005) Arsenate uptake and translocation in seedlings of two genotypes of rice is affected by external phosphate concentrations. Aquat Bot 83:321-331

Girling CA, Peterson PJ (1981) The significance of the cadmium species in uptake and metabolism of cadmium in crop plants. J Plant Nutr 3:707-720

Green CE, Chaney RL, Bouwkamp J (2001) Interactions between cadmium uptake and phytotoxic zinc levels in rice (Oryza sativa L.) using chelator-buffered nutrient solution. Plant Soil 9:20-30

Greipsson S (1994) Effects of iron plaque on roots of rice on growth and metal concentration of seeds and plant tissues when cultivated in excess copper. Commun Soil Sci Plant Anal 25:2761-2769

Greipsson S (1995) Effects of iron plaque on roots of rice on growth of plants in excess zinc and accumulation of phosphorus in plants in excess copper or nickel. J Plant Nutr 18:1659-1665

Greipsson S, Crowder AA (1992) Amelioration of copper and nickel toxicity by iron plaque on roots of rice (Oryza sativa L.). Can J Bot 70:824-830

Hansel CM, Fendorf S, Sutton S, Newville M (2001) Characterization of $\mathrm{Fe}$ plaque and associated metals on the roots of mine-waste impacted aquatic plants. Environ Sci Technol 35:3863-3868

Hansel CM, La Force MJ, Fendorf S, Sutton S (2002) Spatial and temporal association of As and Fe species on aquatic plant roots. Environ Sci Tech 36(9):1988-1994

Hart JJ, Welch RM, Norvell WA, Clarke JM, Kochian LV (2005) Zinc effects on cadmium accumulation and partitioning in near-isogenic lines of durum wheat that differ in grain cadmium concentration. New Phytol 167:391-401

Hassan MJ, Zhang GP, Wu FB, Wei K, Chen ZH (2005) Zinc alleviates growth inhibition and oxidative stress caused by cadmium in rice. J Plant Nutr Soil Sci 168:255-261

Junta Y, Misdutaka Y, Kang YM, Huang B, Luo GB, Takashi K (1998) Heavy metal pollution of agricultural soils and sediments in Liaoning Province, China. Soil Sci Plant Nutr 44 (3):367-375

Kim MC, Shim KH, Chung DH, Cho KT (1980) Heavy metal contents in different bran layers of rice. J Korean Agric Chem Soc 23:141-149

Kukier U, Chaney RL (2002) Growing rice grain with controlled cadmium concentrations. J Plant Nutr 25:1793-1820

Kuo S (1986) Concurrent sorption of phosphate and zinc, cadmium, or calcium by a hydrous ferric oxide. Soil Sci Soc Am J 50:1412-1419

Lagriffoul A, Mocquot B, Mench M, Vangronsveld J (1998) Cadmium toxicity effects on growth, mineral and chlorophyll contents, and activities of stress related enzymes in young maize plants (Zea mays L.). Plant Soil 200:241-250

Liang Y, Zhu YG, Xia Y, Li Z, Ma Y (2006) Iron plaque enhances phosphorus uptake by rice (Oryza sativa) growing under varying phosphorus and iron concentrations. Ann Appl Biol 149:305-312

Liu HJ, Zhang JL, Zhang FS (2007) Role of iron plaque in Cd uptake by and translocation within rice (Oryza sativa L.) seedlings grown in solution culture. Environ Exp Bot 59:314-320

Liu WJ, Zhu YG, Smith FA, Smith SE (2004a) Do iron plaque and genotypes affect arsenate uptake and translocation by rice seedlings (Oryza sativa L.) grown in solution culture? J Exp Bot 55:1707-1713

Liu WJ, Zhu YG, Smith FA, Smith SE (2004b) Do phosphorus nutrition and iron plaque alter arsenate (As) uptake by rice seedlings in hydroponic culture? New Phytol 162:481-488

Liu WJ, Zhu YG, Smith FA (2005) Effects of iron and manganese plaques on arsenic uptake by rice seedlings (Oryza sativa L.) grown in solution culture supplied with arsenate and arsenite. Plant Soil 277:127-138

Moral R, Gomez I, Pedreno JN, Mataix J (1994) Effects of cadmium on nutrient distribution, yield, and growth of tomato grown in soilless culture. J Plant Nutr 17:953-962 
Obata H, Umebayashi M (1997) Effects of cadmium on mineral nutrient concentrations in plants differing in tolerance for cadmium. J Plant Nutr 20:97-105

Otte ML, Rozema J, Koster L, Haarsma MS, Broekman RA (1989) Iron plaque on roots of Aster tripolium L.: Interaction with zinc uptake. New Phytol 111:309-317

Ottow JGG, Benckiser G, Watanabe I (1982) Iron toxicity of rice as multiple nutritional stress. Trop Agr Res Series 15:167-179

Shah K, Kumar RG, Verma S, Dubey RS (2001) Effect of cadmium on lipid peroxidation, superoxide anion generation and activities of antioxidant enzymes in growing rice seedlings. Plant Sci 161:1135-1144

St-Cyr L, Crowder AA (1989) Factors affecting iron plaque on the roots of Phragmites australis (Cav.) Trin. ex Steudel. Plant Soil 116:85-93

Taylor GJ, Crowder AA (1983) Use of the DCB technique for extraction of hydrous iron oxides from roots of wetland plants. Am J Bot 70:1254-1257

Taylor GJ, Crowder AA, Rodden R (1984) Formation and morphology of an iron plaque on the roots of Typha latifolia L. grown in solution culture. Am J Bot 71: 666-675

Tsukahara T, Ezaki T, Moriguchi J, Furuki K, Shimbo S, Matsuda-Inoguchi N, Ikeda M (2003) Rice as the most influential source of cadmium intake among general Japanese population. Sci Tot Environ 305:41-51
Vesk PA, Nockolds CE, Allaway WG (1999) Metal localization in water hyacinth roots from an urban wetland. Plant Cell Environ 22:149-158

Watanabe T, Zhang ZW, Moon CS, Shimbo S, Nakatsuka H, Matsuda-Inoguchi N, Higashikawa K, Ikeda M (2000) Cadmium exposure of women in general populations in Japan during 1991-1997 compared with 1977-1981. Int Arch Occup Environ Health 73:26-34

White MC, Chaney RL (1980) Zinc, cadmium and manganese uptake by soybean from two zinc-amended and cadmiumamended coastal plain soils. Soil Sci Soc Am J 44:308-313

Ye ZH, Baker AJM, Wong MH, Willis AJ (1998) Zinc, lead and cadmium accumulation and tolerance in Typha latifolia as affected by iron plaque on the root surface. Aquat Bot 61:55-67

Ye ZH, Cheung KC, Wong MH (2001) Copper uptake in Typha latifolia as affected by iron and manganese plaque on the root surface. Can J Bot 79:314-320

Zhang XK, Zhang FS, Mao DR (1998) Effect of iron plaque outside roots on nutrient uptake by rice (Oryza sativa L.). Zinc uptake by Fe-deficient rice. Plant Soil 202:33-39

Zhang XK, Zhang FS, Mao DR (1999) Effect of iron plaque outside roots on nutrient uptake by rice (Oryza sativa L.): Phosphorus uptake. Plant Soil 209:187-192

Zhou XB, Shi WM, Zhang LH (2007) Iron plaque outside roots affects selenite uptake by rice seedlings (Oryza sativa L.) grown in solution culture. Plant Soil 290:17-28. 